\title{
ANALISIS MODEL MATEMATIKA PADA KANKER SERVIKS DENGAN PENGELAKAN SISTEM IMUN DAN TERAPI SiRNA
}

\author{
Rara Sandhy Winanda ${ }^{a}$, Joko Purwadi ${ }^{b}$ \\ ${ }^{a}$ Program Studi Matematika FMIPA UAD \\ Jl. Ring Road Selatan, Tamanan, Banguntapan, Bantul Yogyakarta, \\ rara.winanda@math.uad.ac.id \\ b Program Studi Matematika FMIPA UAD \\ Jl. Ring Road Selatan, Tamanan, Banguntapan, Bantul Yogyakarta, joko@math.uad.ac.id
}

\begin{abstract}
ABSTRAK
Pada penelitian ini dibahas tentang dinamika interaksi antara sistem imun dan sel kanker serviks. Model matematika yang terbentuk berupa sistem persamaan biasa non linear yang menjelaskan hubungan interaksi antara sel kanker serviks, sistem imun, senyawa sitokin IL-2, dan senyawa TGF- $\beta$. Pertumbuhan sel kanker serviks dipicu oleh senyawa TGF- $\beta$ dan dihambat oleh pemberian terapi siRNA. Terapi ini bekerja mengurangi jumlah sel kanker serviks dengan menghambat sintesis mRNA yang menambah jumlah sel kanker serviks. Tujuan penulisan paper ini adalah menganalisis dua hal tentang kestabilan titik ekuilibrium bebas kanker dan eksistensi titik ekuilibrium infeksi HPV. Berdasarkan analisis model matematika terhadap lima titik ekuilibirium, yaitu terdiri dari tiga titik ekuilibirum bebas kanker dan dua titik ekuilibrium infeksi HPV, dua titik ekuilibrium bebas kanker bersifat tak stabil dan satu titik ekuilibrium stabil asimtotik dengan syarat tertentu, dan dua titik ekuilibrium infeksi HPV masing-masingnya memuat akar dari polinomial pangkat empat dan pangkat enam. Eksistensi titik ekuilibrium infeksi HPV ditentukan untuk menjamin bahwa kasus ini dapat mempunyai interpretasi biologis.
\end{abstract}

Kata Kunci : Kanker Serviks, Model Matematika, Imonoediting, Terapi siRNA.

\begin{abstract}
In this research, we study a dynamics of immune system and cervical cancer cells. This model consist of several nonlinear ordinary differential equation describing interaction of cervical cancer cells, immune system, IL-2 cytokine, and TGF- $\beta$. The growth of of cervical cancer cells is stimulated by TGF- $\beta$ and it is inhibited by adding SiRNA treatment. This therapy works to eliminate cervical cancer proliferation by targeting specific mRNA sequence which lead to its synthesis. The aim of this paper is to bring together two areas in which stability of free cancer steady states and existence of HPV infection steady states. By analizing the mathematical model to five steady states, that consist of three free cancer steady states and two HPV infection steady states, we found two free cancer steady states is unstable, one free cancer steady states is asymptotical stable, while two HPV infection steady states that consist a polynomial of degree four and six. It is worth pointing out that this steady states has a biological interpretation.
\end{abstract}

\section{Pendahuluan}

$\begin{array}{rrrr} & \text { Kanker serviks merupakan jenis } \\ \text { tumor ganas terbanyak kedua yang }\end{array}$

menyerang wanita di Indonesia. Jumlah penderita kanker serviks di Indonesia diperkirakan sebesar 90-100 jiwa di antara 
100.000 penduduk pertahun (Pradipta, 2007). Kanker ini terutama disebabkan oleh infeksi Human Papillomavirus (HPV), suatu virus DNA yang memiliki delapan ORFs yang terdiri dari enam early protein (E1, E2, E4, E5, E6, dan E7) dan dua late protein (L1 dan L2) yang onkogenik pada organ serviks. (Hakim, 2010).

Kanker serviks dimulai dari infeksi HPV di epitel sel basal pada bagian serviks. Pada saat infeksi, protein E6 dan E7 akan menginaktivasi gen p53 dan pRB pada sel basal, sehingga mekanisme pengontrolan pembelahan sel secara normal menjadi terganggu. Inaktivasi dua gen tersebut merupakan inisiasi munculnya kanker serviks. Selanjutnya, infeksi dapat menyebar ke sel-sel di atas sel basal, bahkan memasuki jaringan limfa untuk berekspansi ke organorgan yang lebih jauh.

Namun, proses ini dapat dihentikan oleh peran sistem imun di dalam tubuh manusia melalui immunosurveillance. Melalui mekanisme ini, sistem imun dapat mencegah dan membatasi pertumbuhan sel kanker. Sistem imun yang kompeten dapat mengenali protein asing yang diekspresikan oleh sel kanker pada inangnya sebagai antigen, kemudian mengirim sinyal pada sel efektor untuk menyerang sel yang terinfeksi tersebut. Beberapa sel efektor yang memiliki peran dalam menyerang sel kanker serviks diantaranya $\mathrm{CD} 8+$, sel $\mathrm{NK}$, sel dendritik (DC), dan sel antibodi (Kresno, 2010).

Di lain pihak, sel kanker juga mempunyai kemampuan untuk mengelak dari pengenalan sel-sel imun. Hal ini dimungkinkan karna adanya proses imunoediting. Mekanisme imunoediting terdiri dari tiga proses yaitu fase eliminasi, ekuilibrium, dan escape [Kresno, 2010]. Melalui proses imunoediting, akan dicetak sel kanker dengan imunogenitas tinggi dan menyisakan sel kanker dengan imunogenitas rendah. Proses ini menghasilkan sel kanker yang resisten terhadap aktivitas penyerangan imun sehingga bertahan dalam sel inangnya yang imunokompeten. Sel yang berperan dalam proses penekanan sel-sel imun ini antara lain Interleukin-10 (IL-10), Prostaglandin E2 (PGE2), dan Transforming Growth Factor-Beta (TGF- $\beta$ ) (Arciero, 2014).

Beberapa penelitian yang telah mengkaji dinamika antara sel kanker dengan sistem imun diantaranya Dougan (2009), Restifo (2012), Kirschner (1998) dan Adi (2016). Berdasarkan penelitian Kirschner (1998), tumor tanpa pemberian terapi menunjukkan kondisi tumor yang bertahan di dalam tubuh manusia, sedangkan imunoterapi dengan terapi IL-2 juga tidak 
menghasilkan kesembuhan pada pasien. Diduga, hal ini diakibatkan karena sel tumor atau kanker telah melalui fase eliminasi dan memasuki fase escape sehingga bisa mengelak dari mekanisme respon imun. Penelitian Adi (2016) membahas tentang bifurkasi pada pemodelan sel kanker serviks dengan sistem imun dengan pengaruh imunoterapi.

Pada paper ini, akan dibahas dinamika sistem imun dan sel kanker serviks dengan kasus kanker serviks yang mencapai fase escape. Sel yang dikaji sebagai penekan sel imun adalah sel TGF- $\beta$. Selanjutnya, digunakan terapi untuk mereduksi jumlah TGF- $\beta$ dengan terapi siRNA pada sel kanker serviks. Terapi siRNA merupakan rangkaian proses mikroseluler yang berperan menghambat terbentukanya TGF- $\beta$ di dalam sel kanker serviks. Dengan demikian, penelitian ini diharapkan dapat berguna untuk meninjau proses escape sel kanker serviks dan peran terapi siRNA dalam penyembuhan pasien kanker serviks.

\section{Formulasi Model Matematika}

Model matematika yang digunakan pada paper ini merujuk pada model matematika dinamika tumor-imun yang dikerjakan oleh Sharma (2013) dan penambahan efek pemberian terapi siRNA mengikuti model yang dikerjakan Arciero (2004) dengan tambahan faktor terapi mengalami gangguan kecil $(\varepsilon)$. Sehingga dibentuk model matematika berikut ini.

$$
\begin{aligned}
& \frac{d E}{d \bar{t}}=\bar{b} E I-\bar{a}_{1} T E-\bar{p}_{1} T S-\bar{d}_{1} E \\
& \frac{d T}{d \bar{t}}=\bar{r}_{1} T\left(1-\bar{p}_{2} T\right)-\bar{a}_{2} E T+\bar{a}_{3} T S \\
& \frac{d I}{d \bar{t}}=\bar{r}_{2} I\left(1-\bar{p}_{3} I\right)-\bar{b} E I-\bar{d}_{2} I \\
& \frac{d S}{d \bar{t}}=\frac{\bar{p}_{4} T^{2}}{\bar{\tau}^{2}+T^{2}}-\bar{\mu}_{3} S-\bar{\varepsilon} \bar{\eta} T
\end{aligned}
$$

dengan nilai awal:

$$
E(0)=E_{0}, \quad T(0)=T_{0}, \quad I_{L}(0)=I_{L 0},
$$

Pada model di atas, $\mathrm{E}(\mathrm{t}), \mathrm{T}(\mathrm{t}), \mathrm{I}(\mathrm{t})$, dan $\mathrm{S}(\mathrm{t})$ masing-masingnya menunjukkan laju perubahan sel efektor, sel kanker serviks, sel IL-2 dan TGF- $\beta$ terhadap waktu $t$. Semua parameter berupa konstanta positif.

Persamaan (1) menunjukkan laju penambahan jumlah sel efektor sebanding dengan jumlah senyawa IL-2 yang dihasilkan. Efek interaksi antara sel efektor dengan sel kanker serviks dilambangkan dengan $\bar{b}_{1}$ dan faktor interaksi sel kanker serviks dengan sel $T G F-\beta$ dinotasikan dengan $\bar{p}_{1}$. Sedangkan pengurangan jumlah sel efektor dengan laju eliminasi $\bar{d}_{1}$.

Persamaan kedua menunjukkan laju perubahan jumlah sel kanker serviks dengan 
asumsi pertumbuhannya mengikuti fungsi logistik dengan angka pertumbuhan sebesar $\bar{r}_{1}$ dan kapasitas batas sebesar $\bar{p}_{2}$. Penambahan sel kanker serviks karena efek interaksi antara sel kanker serviks dengan sel $T G F-\beta$ dengan koefisien interaksi sebesar $\bar{a}_{3}$, sedangkan pengurangannya karena interaksi dengan sel efektor sebesar $\bar{a}_{2}$. Sel kanker diasumsikan tidak memiliki kematian alami karena sel kanker membelah terus tanpa batas akibat disregulasi gen penghambat pertumbuhan sel normal.

Persamaan (3) menunjukkan laju perubahan jumlah senyawa IL-2 dimana pertumbuhannya mengikuti fungsi logistik dengan angka pertumbuhan sebesar $\bar{r}_{2}$ dan kapasitas batas sebesar $\bar{p}_{3}$. Efek interaksi dengan sel efektor mengurangi jumlah senyawa IL-2 sebesar $\bar{b}$. Senyawa IL-2 memiliki kematian alami yaitu sebesar $\bar{d}_{2}$.

Persamaan terakhir mendeskripsikan laju perubahan jumlah $T G F-\beta$ terhadap waktu dengan menggunakan asumsi reaksi biokimia untuk pembentukannya dinyatakan melalui fungsi Hills. Kematian alami TGF $-\beta$ sebesar $\bar{\mu}_{3}$. Sedangkan efek terapi siRNA dinyatakan pada suku terakhir Persamaan (4) dengan parameter $\bar{\eta}$ dan fakto gangguan sebesar $\bar{\varepsilon}$.
Pada penelitian ini dilakukan analisis model matematika hasil non-dimensionalisi dengan menggunakan variabel-variabel nondimensionalisi berikut ini:

$$
\begin{aligned}
& w=\frac{E}{\bar{a}_{1}}, \quad x=\frac{T}{\bar{a}_{2}}, \quad y=\frac{I}{\bar{a}_{1}}, \quad z=\frac{S}{\bar{\mu}_{3}}, \\
& t=\bar{d}_{2} \bar{t}, \quad b=\frac{\bar{b} \bar{d}_{1}}{\bar{a}_{1} \bar{d}_{2}}, \quad a_{1}=\frac{\bar{a}_{1} \bar{a}_{2}}{\bar{d}_{2}}, \quad p_{1}=\frac{\bar{p}_{1} \bar{a}_{2} \bar{\mu}_{3}}{\bar{a}_{1} \bar{d}_{2}} \\
& r_{1}=\frac{\bar{r}_{1}}{\bar{d}_{2}}, \quad p_{2}=\bar{p}_{2} \bar{a}_{2}, a_{2}=\frac{\bar{a}_{2} \bar{a}_{1}}{\bar{d}_{2}}, \quad a_{3}=\frac{\bar{a}_{3} \bar{\mu}_{3}}{\bar{d}_{2}} \\
& r_{2}=\frac{\bar{r}_{2}}{\bar{d}_{2}}, p_{3}=\bar{p}_{3} \bar{a}_{1}, \quad p_{4}=\frac{\bar{p}_{4}}{\bar{\mu}_{3} \bar{d}_{2} \bar{a}_{2}}, \tau=\frac{\bar{\tau}_{2}}{\bar{a}_{2}} \\
& \mu_{3}=\frac{\bar{\mu}_{3}}{\bar{d}_{2}}, \quad \varepsilon=\bar{\varepsilon}, \quad \eta=\frac{\bar{\eta} \bar{a}_{2}}{\bar{d}_{2} \bar{\mu}_{3}}, \quad d_{1}=\frac{\bar{d}_{1}}{\bar{d}_{2}}
\end{aligned}
$$

Hasil non dimensionalisasi dari Sistem (1) -(5) adalah sebagai berikut.

$$
\begin{aligned}
& \frac{d w}{d t}=-a_{1} w x+b w y-p_{1} x z-d_{1} w \\
& \frac{d x}{d t}=r_{1} x\left(1-p_{2} x\right)-a_{2} w x+a_{3} x z \\
& \frac{d y}{d t}=r_{2} y\left(1-p_{3} y\right)-b w y-y \\
& \frac{d z}{d t}=\frac{p_{4} w^{2}}{\tau^{2}+w^{2}}-\mu_{3} \mathrm{y}-\varepsilon \eta x
\end{aligned}
$$$$
\text { dengan nilai }
$$

$w(0)=w_{0}, \quad x(0)=x_{0}, \quad y(0)=y_{0}, \quad z(0)=z_{0}$ (10).

\section{Hasil dan Pembahasan}

Analisis model matematika (6)- (10) menghasilkan dua jenis titik ekuilibrium yaitu titik ekuilibrium bebas kanker (untuk 
$x=0$ ) dan titik ekuilibrium infeksi HPV

(untuk $x \neq 0$ ).

\section{Titik Ekuilibrium Bebas Kanker}

Diperoleh tiga titik ekuilibrium bebas kanker yaitu $E_{0}, E_{1}$, dan $E_{2}$ sebagai berikut

$$
\begin{aligned}
& E_{0}=(0,0,0,0), \\
& E_{1}=\left(-\frac{d_{1} p_{3} r_{2}+b d_{2}-b r_{2}}{b^{2}}, 0, \frac{d_{1}}{b}, 0\right) \\
& E_{2}=\left(0,0,-\frac{d_{2}-r_{2}}{p_{3} r_{2}}, 0\right)
\end{aligned}
$$

Titik ekuilibrium $E_{0}$ disebut ekuilibrium titik ekuilibrium trivial dan pada realitasnya hal ini bermakna tidak ada. Tapi, kita bisa mengamati perilaku solusi lain di sekitar titik ekuilibirum ini. Kestabilan lokal di sekitar titik ekuilibrium $E_{0}$ diperoleh dengan linearisasi menggunakan Matriks Jacobian sehingga diperoleh empat nilai eigen yaitu $\lambda_{1}=-d_{1}, \lambda_{2}=r_{1}, \lambda_{3}=-d_{2}+r_{2}, \lambda_{4}=-d_{3}$.

Karena $\lambda_{2}$ bernilai positif, maka titik ekuilibrium $E_{0}$ tidak stabil

Untuk titik ekuilibrium $E_{1}$ diperoleh 4 nilai eigen sebagai berikut:

$$
\lambda_{1}=\frac{\left(a_{2} d_{1} p_{3} r_{2}+a_{2} b d_{2}-a_{2} b r_{2}+b^{2} r_{1}\right)}{b^{2}},
$$

$\lambda_{2}=-d_{3}$,

$$
\begin{aligned}
& \lambda_{3}=\frac{-d_{1} p_{3} r_{2}+\sqrt{\begin{array}{l}
\left(d_{1}^{2} p_{3}{ }^{2} r_{2}^{2}+4 b d_{1}^{2} p_{3} r_{2}\right. \\
\left.+4 b^{2} d_{1} d_{2}-4 b^{2} d_{1} r_{2}\right)
\end{array}}}{2 b} \\
& \lambda_{4}=-\frac{d_{1} p_{3} r_{2}+\sqrt{\begin{array}{l}
\left(d_{1}^{2} p_{3}{ }^{2} r_{2}^{2}+4 b d_{1}^{2} p_{3} r_{2}\right. \\
\left.+4 b^{2} d_{1} d_{2}-4 b^{2} d_{1} r_{2}\right)
\end{array}}}{2 b}
\end{aligned}
$$

Untuk menentukan kestabilan titik ekuilibrium $E_{1}$ dibentuk Teorema berikut ini.

Teorema 1. Diberikan pertaksamaanpertaksamaan berikut:

$$
\begin{aligned}
& \text { (i) } d_{2}<r_{2}-\left(\frac{a_{2} d_{1} p_{3} r_{2}+b^{2} r_{1}}{a_{2} b}\right) \\
& \text { (ii) } d_{2} \geq r_{2}-\left(\frac{p_{3} r_{2}\left(p_{3} r_{2}+4 b\right)}{4 b^{2}}\right) \\
& \text { (iii) } d_{2}<r_{2}-\frac{d_{1} p_{3} r_{2}}{b}
\end{aligned}
$$

Jika $d_{2}$ memenuhi ketiga kondisi di atas, maka titik ekuilibrium $E_{1}$ stabil asimtotik.

\section{Bukti:}

Agar titik ekuilibrium $E_{1}$ stabil asimtotik maka semua nilai eigen harus bernilai negatif. Diperhatikan

$\lambda_{1}=\frac{\left(a_{2} d_{1} p_{3} r_{2}+a_{2} b d_{2}-a_{2} b r_{2}+b^{2} r_{1}\right)}{b^{2}}$ bernilai negatif jika $d_{2}<r_{2}-\frac{\left(a_{2} d_{1} p_{3} r_{2}+b^{2} r_{1}\right)}{a_{2} b}$.

Nilai $\lambda_{3}$ eksis jika nilai parameter di bawah tanda akar positif atau nol. Hal ini terpenuhi jika 
$d_{2} \geq r_{2}-\frac{p_{3} r_{2}\left(p_{3} r_{2}+4 b\right)}{4 b^{2}}$. Selanjutnya $\lambda_{3}<0$ jika $d_{2}<r_{2}-\frac{d_{1} p_{3} r_{2}}{b}$. Sedangkan $\lambda_{4}$ jelas bernilai negatif dengan syarat eksistensi jika memenuhi persamaan di atas.

Pada titik ekuilibrium bebas kanker $E_{2}$ diperoleh kestabilan dengan menggunakan Matriks Jacobian dengan nilai eigen $\lambda_{1}=r_{1}, \lambda_{2}=d_{2}-r_{2}, \quad \lambda_{3}=-d_{3}, \quad$ dan $\lambda_{4}=-\frac{d_{1} p_{3} r_{2}+b d_{2}-b r_{2}}{p_{3} r_{2}}$. Karna $\lambda_{1}>0$ maka titik ekuilibirum $E_{2}$ tidak stabil.

Jadi, pada titik ekuilibrium bebas kanker diperoleh dua titik ekuilibrium yang tidak stabil dan satu titik ekuilibirum stabil asimtotik dengan syarat-syarat sesuai Teorema 1 .

\section{Titik Ekuilibrium Infeksi HPV}

Dari sistem persamaan (6)- (10) diperoleh dua titik ekuilibrium infeksi HPV yaitu $E_{3}$ dan $E_{4}$. Titik ekuilibrium ini masing-masingnya memuat akar dari polinomial pangkat empat dan polinomial pangkat enam. Sehingga titik ekuilibrium ini dianalisis dengan mencari syarat eksistensinya. Sedangkan untuk kestabilan lokal di sekitar titik ekuilibirum infeksi HPV tidak dikerjakan dalam paper ini.
Pada kondisi $I L-2$ tidak ada, diperoleh titik ekuilibirium $E_{3}=\left(w^{*}, x^{*}, 0, z^{*}\right)$, dimana

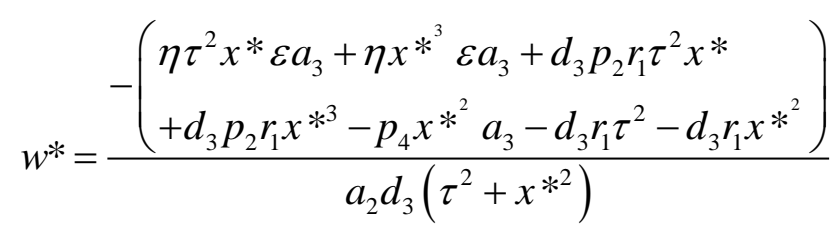

$$
\begin{aligned}
& x^{*}=b_{1} x^{4}+b_{2} x^{3}+b_{3} x^{2}+b_{4} x+b_{5}=0 \\
& z^{*}=\frac{\left(-x^{*} x^{* 2} \eta \varepsilon+\eta \tau^{2} \varepsilon-x^{*} p_{4}\right)}{d_{3}\left(\tau^{2}+x^{* 2}\right)}
\end{aligned}
$$

Diperhatikan bahwa $x^{*}$ merupakan akar dari polinomial pangkat 4

$$
b_{1} x^{4}+b_{2} x^{3}+b_{3} x^{2}+b_{4} x+b_{5}=0
$$

(tanpa tanda *) dengan nilai masing-masing:

$$
\begin{aligned}
& b_{1}=\eta\left(a_{1} a_{3}+a_{2} p_{1}\right) \varepsilon+a_{1} d_{3} p_{2} r_{1} \\
& b_{2}=-r_{1}\left(-d_{1} p_{2}+a_{1}\right) d_{3}+\left(d_{1} \eta \varepsilon-a_{1} p_{4}\right) a_{3}-a_{2} p_{1} p_{4} \\
& b_{3}=\left(\eta\left(a_{1} a_{3}+a_{2} p_{1}\right) \varepsilon+a_{1} d_{3} p_{2} r_{1}\right) \tau^{2}-d_{1}\left(a_{3} p_{4}+d_{3} r_{1}\right) \\
& b_{4}=-\tau^{2}\left(r_{1}\left(-d_{1} p_{2}+a_{1}\right) d_{3}-a_{3} d_{1} \eta \varepsilon\right) \\
& b_{5}=-d_{1} d_{3} r_{1} \tau^{2}
\end{aligned}
$$

\section{Untuk menghitung akar polinomial} (11) dibentuk variabel baru yaitu

$$
\begin{gathered}
c_{i}=\frac{b_{i+1}}{b_{1}}, i=1, . .4, \\
d_{1}=\sqrt{\frac{1}{4} c_{1}^{2}+c_{2}+e_{1}}
\end{gathered}
$$




$$
\begin{aligned}
& d_{2}= \begin{cases}\sqrt{\frac{3}{4} c_{1}^{2}-d_{1}^{2}-2 c_{2}} & \text { jika } \mathrm{d}_{1} \neq 0 \\
\sqrt{\frac{1}{4}\left(4 c_{1} c_{2}-8 c_{3}-c_{1}^{3}\right) d_{1}^{-1}} & \end{cases} \\
& d_{2}= \begin{cases}\sqrt{\frac{3}{4} c_{1}^{2}-d_{1}^{2}-2 c_{2}} & \text { jika } \mathrm{d}_{1} \neq 0 \\
\sqrt{\frac{1}{4}\left(4 c_{1} c_{2}-8 c_{3}-c_{1}^{3}\right) d_{1}^{-1}} & \\
\sqrt{4} c_{2}+2 \sqrt{e_{1}^{2}-4 c_{4}}, & \text { jika } \mathrm{d}_{1}=0\end{cases} \\
& x_{1}=-\frac{c_{1}}{4}+\frac{1}{2}\left(d_{1}+d_{2}\right) \quad x_{3}=-\frac{c_{1}}{4}-\frac{1}{2}\left(d_{1}-d_{2}\right) \\
& x_{2}=-\frac{c_{1}}{4}+\frac{1}{2}\left(d_{1}-d_{2}\right) \quad x_{4}=-\frac{c_{1}}{4}-\frac{1}{2}\left(d_{1}+d_{2}\right) \\
& \text { Jadi titik ekuilibrium } E_{3} \text { terdiri atas } \\
& \text { empat titik ekuilibrium yaitu } E_{3}^{i}, i=1, . ., 4 \text {. } \\
& \text { Eksistensi titik ekuilibrium } \\
& E_{3}^{i}, i=1, . ., 4 \text { diperoleh dari Teorema } 2 \text { dan }
\end{aligned}
$$$$
d_{3}= \begin{cases}\sqrt{\frac{3}{4} c_{1}^{2}-d_{1}^{2}-2 c_{2}} & \text { jika } \mathrm{d}_{1} \neq 0 \\ \sqrt{\frac{1}{4} c_{1}^{2}-2 c_{2}-2 \sqrt{e_{1}^{2}-4 c_{4}}}, & \text { jika d } c_{1}=0\end{cases}
$$$$
e_{1}=g_{1}-\frac{1}{3} \sqrt[3]{\frac{1}{2}\left(g_{2}+\sqrt{g_{2}^{2}-4 g_{3}^{3}}\right)}
$$$$
-\frac{1}{3} \sqrt[3]{\frac{1}{2}\left(g_{2}-\sqrt{g_{2}^{2}-4 g_{3}^{3}}\right)}
$$$$
f_{1}=1, f_{2}=-c_{2}, f_{3}=c_{1} c_{3}-4 c_{4}, f_{4}=4 c_{2} c_{4}-c_{3}^{2}-c_{1}^{2} c_{4}
$$$$
g_{1}=-\frac{f_{2}}{3}, g_{2}=2 f_{2}^{3}-9 f_{2} f_{3}+27 f_{4}, g_{3}=f_{2}^{2}-3 f_{3}^{3}
$$

Teorema 2. Jika $d_{1}=0$,

$$
\begin{aligned}
& \frac{\left(\tau^{2}+x^{2}\right)\left(\eta \varepsilon a_{3} x+d_{3} p_{2} r_{1} x-d_{3} r_{1}\right)}{x^{2} a_{3}} \leq p_{4} \\
& \leq \frac{\eta \varepsilon\left(\tau^{2}-x^{2}\right)}{x}
\end{aligned}
$$

dan memenuhi kondisi berikut:

$$
\text { i) } \begin{gathered}
16 b_{1} b_{2}^{2} b_{3}-5 b_{2}^{4}-256 b_{1}^{3} b_{5} \geq 0, b_{2} \geq 0, \\
-b_{2}^{2}+4 b_{1} b_{3} \geq 0 \text {, dan } 8 b_{1} b_{3}-3 b_{2}^{2} \geq 0 .
\end{gathered}
$$

Maka titik ekuilibrium $E_{3}^{1}$ eksis.

ii) $16 b_{1} b_{2}^{2} b_{3}-5 b_{2}^{4}-256 b_{1}^{3} b_{5} \leq 0, \quad b_{2} \leq 0$, $-b_{2}^{2}+4 b_{1} b_{3} \leq 0$, dan $8 b_{1} b_{3}-3 b_{2}^{2} \leq 0$.

Maka titik ekuilibrium $E_{3}^{4}$ eksis.

Teorema 3. Jika $d_{1}>0$,

Sehingga diperoleh solusi dari persamaan (11) yaitu

$$
\begin{aligned}
& \frac{\left(\tau^{2}+x^{2}\right)\left(\eta \varepsilon a_{3} x+d_{3} p_{2} r_{1} x-d_{3} r_{1}\right)}{x^{2} a_{3}} \leq p_{4}, \\
& \leq \frac{\eta \varepsilon\left(\tau^{2}-x^{2}\right)}{x}
\end{aligned},
$$




$$
\begin{aligned}
& h_{2}=\frac{3 b_{2}^{2} d_{1}}{8 b_{1}}-\frac{b_{1} d_{1}^{3}}{2}-b_{3} d_{1}, h_{3}=\frac{b_{2} b_{3}}{2 b_{1}}-\frac{b_{2}^{3}}{8 b_{1}^{2}}, h_{4}=2 b_{1} d_{1} \\
& h_{5}=3 b_{2}^{2}-4 b_{1}^{2} d_{1}^{2}-8 b_{1} b_{3} \text { dan } \\
& b_{6}=\frac{4 b_{2} b_{3}-8 b_{1} b_{4}-\frac{b_{2}^{3}}{b_{1}}}{d_{1}},
\end{aligned}
$$

serta memenuhi salah satu syarat berikut:

i) $b_{4} \leq h_{2}+h_{3}, b_{2}<h_{4}+\sqrt{h_{5}+h_{6}}$ maka $E_{3}^{1}$

eksis,

ii). $b_{4} \leq h_{2}+h_{3}, b_{2}<h_{4}-\sqrt{h_{5}+h_{6}}$ maka titik ekuilirbium $E_{3}^{2}$ eksis ,

iii). ) $b_{4} \geq-h_{2}+h_{3}, b_{2}<-h_{4}+\sqrt{h_{5}-h_{6}}$ maka

titik ekuilibrium $E q_{3}^{3}$ eksis, dan

iv). $b_{4} \geq-h_{2}+h_{3}, b_{2}<-h_{4}-\sqrt{h_{5}-h_{6}}$ maka

titik ekuilirium $E_{3}^{4}$ eksis.

Pembuktian untuk Teorema 2 dan

Teorema 3 dapat merujuk pada (Adi, 2016).

\section{Simulasi Numerik}

Simulasi numerik sistem persamaan (6) - (10) menggunakan nilai-nilai parameter berikut ini.

Tabel 1. Nilai Parameter

\begin{tabular}{|l|l|}
\hline Nama & Nilai \\
\hline$b$ & $6,92 \times 10^{-9}$ \\
\hline$a_{1}$ & $3,422 \times 10^{-10}$ \\
\hline$d_{1}$ & $4,12 \times 10^{-3}$ \\
\hline$r_{1}$ & 0,44 \\
\hline$a_{2}$ & $1,101 \times 10^{-7}$ \\
\hline$r_{2}$ & 0,0245 \\
\hline$p_{3}$ & $1 \times 10^{-10}$ \\
\hline$p_{1}$ & 0,1245 \\
\hline$p_{2}$ & $5 \times 10^{-9}$ \\
\hline$a_{3}$ & 0,27 \\
\hline
\end{tabular}

\begin{tabular}{|l|l|}
\hline$d_{2}$ & 10 \\
\hline$q_{1}$ & 0,1121 \\
\hline$p_{4}$ & $2 \times 10^{8}$ \\
\hline$\tau_{c}$ & $1 \times 10^{6}$ \\
\hline$\mu_{3}$ & 10 \\
\hline$\varepsilon$ & 0,0001 \\
\hline$\eta$ & 0,66 \\
\hline
\end{tabular}

Dari hasil simulasi numerik menggunakan Matlab dengan nilai parameter dari Tabel 1, diperoleh diagram trayektori dan potret fase pada gambar-gambar berikut.

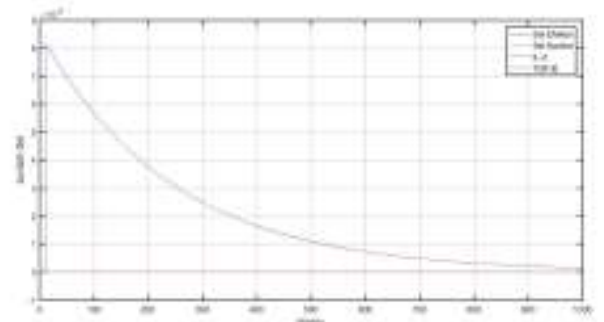

Gambar 1. Diagram Trayektori Sistem Persamaan (6)(10) dengan $\mathrm{t}=1000$.

Pada Gambar 1 dengan $\mathrm{t}=1000$ terlihat bahwa jumlah sel efektor pada mulanya naik hingga nilai lebih dari $8 \times 10^{11}$ dan setelah itu mengalami penurunan eksponensial menuju nilai nol. Sedangkan nilai dari variabel lain (sel kanker serviks, IL-2 dan $T G F-\beta$ ) sangat kecil dan mendekati nilai nol.

Pada Gambar 2, diamati dua variabel yaitu sel kanker serviks dan sel efektor pada saat $t=3000$. Hasil simulasi numerik menunjukkan bahwa jumlah sel kanker 
serviks sangat kecil dibandingkan sel efektor.

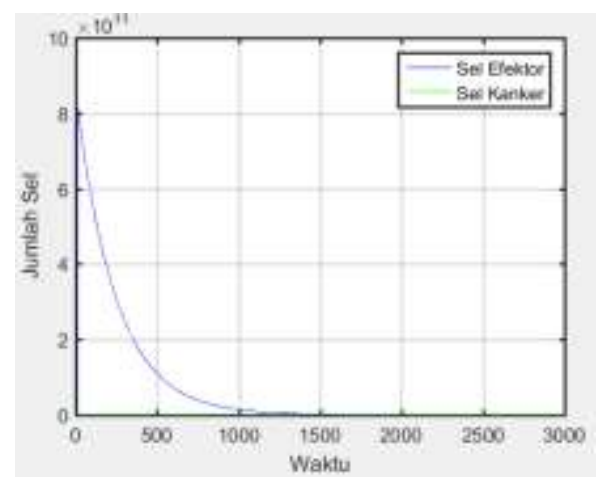

Gambar 2. Diagram Trayektori Model (6)-(10) untuk variabel sel efektor dan sel kanker dengan $\mathrm{t}=3000$.

Gambar 2 menunjukkan bahwa sel kanker serviks mengalami kenaikan yang tidak sama dengan sel efektor. Akibatnya sel kanker serviks dengan cepat menuju nilai nol. Dengan kata lain, pasien pendertita kanker serviks dapat disembuhkan dengan menggunakan terapi siRNA.

\section{Kesimpulan}

Hasil analisis model matematika antara sistem imun dan sel kanker serviks dengan peran senyawa $I L-2$ dan $T G F-\beta$ menunjukkan terdapat lima titik ekuilibirum, yaitu dua titik ekuilibrium bebas kanker yang bersifat tak stabil, satu titik ekuilibirum bebas kanker yang stabil dengan syarat tertentu, serta diperoleh 4 titik ekuilibrium infeksi HPV (4 titik $E_{3}^{i}, i=1, . ., 4$ ) yang dijamin eksistensinya melalui Teorema 2 dan Teorema 3.
Untuk titik ekuilibrium bebas kanker, jika dipenuhi kondisi pada Teorema 1 maka kondisi kesembuhan pasien kanker serviks dapat diperoleh. Sedangkan untuk titik ekuilibrium infeksi HPV, dengan menunjukkan eksistensinya, berarti membuka jalan pada penelitian lain untuk mengamati perilaku solusi di sekitar titik ekuilibirum ini.

Simulasi numerik menunjukkan bahwa pada model matematika interaksi sistem imun dengan sel kanker serviks dengan bantuan terapi siRNA dapat mengeliminasi jumlah sel kanker serviks sehingga pasien sel kanker serviks dapat disembuhkan.

Penelitian ini dapat dilanjutkan dengan memperkaya serta memperdalam analisis dinamika interaksinya. Adapun beberapa saran untuk penelitian lanjutan yaitu:

1. Melakukan analisis bifurkasi pada titik ekuilibrium infeksi HPV $E q_{3}^{i}, i=1, \ldots, 4$ agar memperoleh kestabilan pada daerah-daerah yang berbeda secara topologis.

2. Mengkaji $E_{4}$ yang memuat akar dari polinomial pangkat enam.

3. Membandingkan efek pemberian terapi siRNA dengan alternatif pengobatan yang lain, misalnya 
kemoterapi atau immunoterapi dan melihat efek dari penggunaan gabungan metode-metode pengobatan pada kanker serviks.

Demikian beberapa rekomendasi untuk penelitian selanjutnya. Semoga dapat memperluas kajian serta memperdalam analisis dari model matematika ini.

\section{Ucapan Terimakasih}

Ucapan terimakasih kami sampaikan kepada Direktorat Riset dan Pengabdian Masyarakat, Direktorat Jenderal Penguatan Riset dan Pengembangan, Kementrian Riset, Teknologi, dan Pendidikan Tinggi DIKTI yang telah memberikan hibah bantuan Penelitian Dosen Pemula tahun 2017. Selanjutnya kepada Program Studi Matematika, FMIPA, Universitas Ahmad Dahlan atas motivasi dan kerjasama selama penelitian ini berlangsung.

\section{Pustaka}

Adi-Fajar, K, dan. Rara, S.W., 2016, Bifurcation Analysis of the Cervical Cancer Cells, Effector Cells, and IL-2 Compound Interaction with Immunotherapy. Far East Jounal of Mathematical Sciences. 99 :869-883.

Arciero., J.C., Jackson., T.L., Kirschner., D.E. 2004. A Mathematical Model of
Tumor-Immune Evasion and siRNA

Treatment. AIM Sciences. 4:39-58.

Dougan, M., and Dranoff, G. 2009. Annual Review of Immunology. Immunotheraphy for Cancer. 27 :83117.

Garcea, R.L., 2007. The Papillomaviruses, Springer, New York.

Hakim, L., 2010. Biologi dan Patogenesis Human Pappilomavirus. PKB. New Perspective of Sexually Transmitted Problem. P. 164-180.

IARC. 2007. Cervical Cancer Screening. International Agency for Research on Cancer Handbook of Cancer Prevention. France.

Kirschner, D. \& Panetta. J.C. 1998. Modelling Immunotherapy of the Tumor Immune Interaction. Journal of Mathematical Biology. 37: 235252.

Kresno, S.B., 2010. Imunologi. FK Universitas Indonesia. Jakarta.

Pradipta,B., dan Sungkar, S., 2007. Penggunaan vaksin HPV dalam Pencegahan Kanker Serviks. Majalah Kedokteran Indonesia, 57.

Restifo, N.P., et al. 2012. Adoptive Immunotherapy for Cancer: Hernessing the T-Cell Response. Nature Review. 12 :269-281.

Sharma, Swarnali, and Samanta, G.P. 2013. Dinamical Behaviour of a Tumor Immune System with Chemotherapy and Optimal Control. Journal of Nonlinear Dynamics. 2013:1-13.

Stern,P.L., \& Einstein, M.H. 2012. The Immunology of

Human

Papillomavirus Associated Oncogenesis. Springer

Science+Business Media. UK.

WHO ICO HPV Information Centre. 2014. Human papillomavirus and Related Diseases report. 